Karolina Burnagiel

\title{
Komentarz leksykograficzny do frazeologizmu mój cyrk, moje malpy
}

Od pewnego czasu można zaobserwować w języku rosnącą popularność związku frazeologicznego mój cyrk, moje małpy, a także ekspansję różnych jego wariantów, głównie zawierających alternacje w postaci negacji. Trudno jest jednoznacznie określić, która $\mathrm{z}$ tych postaci - mój cyrk, moje matpy, czy też nie mój cyrk, nie moje małpy pojawiła się pierwsza w języku. Obie formy są zanotowane w źródłach słownikowych, przy czym wersja bez negacji pojawiła się o kilka lat później od postaci zanegowanej. W Wielkim słowniku frazeologicznym idiom mój cyrk, moje matpy zdefiniowano jako: 'teraz sam się martw, to jest twoja sprawa, ty za to odpowiadasz'. Najprościej mówiąc, wyrażenie to jest używane dla dobitnego stwierdzenia, że coś dotyczy wyłącznie jednej strony interakcji. Większą frekwencję tak w Narodowym Korpusie Języka Polskiego, jak i w cytatach internetowych wykazuje fraza nie mój cyrk, nie moje małpy. W Nowym słowniku frazeologicznym Renardy Lebdy zdefiniowano ten wariant następująco: 'to nie mój interes, więc nie obchodzi mnie to'2 . Henryk Markiewicz i Andrzej Romanowski w Skrzydlatych słowach ${ }^{3}$ przypisuja autorstwo tego frazeologizmu Ireneuszowi

1 Mój cyrk, moje matpy [hasło], w: P. Fliciński, Wielki stownik frazeologiczny, Poznań 2012, s. 278. Lepszym rozwiązaniem byłoby ustalenie formy słownikowej w postaci twój cyrk, twoje matpy, ponieważ definicja wskazywałaby na użycie związku frazeologicznego w stosunku do adresata wypowiedzi.

2 Nie mój cyrk, nie moje matpy [hasło], w: R. Lebda, Nowy stownik frazeologiczny, Kraków 2005, s. 57.

3 Nie mój cyrk, nie moje matpy [hasło], w: H. Markiewicz, A. Romanowski, Skrzydlate słowa: wielki słownik cytatów polskich i obcych, Kraków 2005. 
Sekule, który w 1993 roku odniósł się w ten sposób do rządu Hanny Suchockiej. Oto kilka przykładów ilustrujących różne warianty omawianego frazeologizmu:

MÓJ CYRK, NIE MOJE MAŁPY Nie, nie pomyliłem się w tytule. Niestety. Chciałoby się powiedzieć tak, jak mówi się zwykle: „nie mój cyrk, nie moje małpy”. Ale cyrk o nazwie „Polska” jest mój, Twój i tej Pani też. Po tej debacie prezydenckiej nic nie będzie takie samo. Mogę jasno stwierdzić, że żadna z osób mnie nie przekonała. Jest jeszcze gorzej. Większość spowodowała, że potwierdziłem moje najgorsze opinie na ich temat. Zwycięzców jest trzech, plus jeden nieobecny ${ }^{4}$;

O ile niedawno jeden z polityków o powiedział działaniach rządu „Nie moje małpy, nie mój cyrk", to ja mam troszkę inne zdanie, bo o ile małpy fatycznie należą do Premiera i Prezydenta, to ja też mieszkam w tym cholernym cyrku! I strasznie mi się niepodobna, co w tym cyrku odwalają kierujący nim klauni! $!^{5}$;

- Nie mój cyrk, nie moje małpy - powiedział Lech, legendarny założyciel nadwarciańskiego grodu i udał się na mecz swojego dużo młodszego imiennika. Wasze wojenki, drodzy rodacy, naprawdę nas nie interesują. Kiedy cała Polska szykuje się do starcia dwóch licznie reprezentowanych skrajnych światopoglądów, my pieczemy rogale świętomarcińskie. Kiedy w całej Polsce zwaśnione strony wychodzą na ulicę, aby bardzo dobitnie wyartykułować swoje zdanie na temat życia, wszechświata i całej reszty (bardzo dobitnie), my zamykamy najważniejszą ulicę w samym centrum miasta i robimy sobie imprezkę;

Ależ oczywiście! Kierowca jest właścicielem firmy prywatnej o nazwie 'jego bis' i zawsze może powiedzieć „moje malpy - mój cyrk”. Jak inteligenciki, studenciki i inni jajogłowi chcieli zachować jakąkolwiek kontrolę nad tym co się dzieje w busach i autobusach, to nie należało doprowadzać, w imię prywatyzacyjnej ideologii, do likwidacji PKS-ów. W firmie PKS istniała formalna ścieżka dochodzenia swoich praw, busiarze to są spółki z .o.o. widać ci jajogłowi nie okazali się tacy znowu jajogłowi, skoro nie przewidzieli że tak to prywatyzacyjne szaleństwo się dla nich skończy (wiem,

4 https://politycznewycinki.wordpress.com/category/na-prawicy/korwin [dostęp: 24.05.2016]. Pisownia wszystkich cytatów oryginalna, wytłuszczenia odautorskie.

5 http://blogpress.pl/node/7392 [dostęp: 24.05.2016].

6 S. Woźniak, Poznański dzień niepodległości, http://igoronco.natemat.pl/ 38785,poznanski-dzien-niepodleglosci [dostęp: 24.05.2016]. 
wiem, były przypadki łamania praw pasażera w PKS, ale to wciąż była instytucja państwowa, a nie bus z o.o.; odpowiedzialni w powiecie za likwidację PKS będą się chyba w piekle smażyć za to zrobili) ${ }^{7}$;

Pilch, kibic Cracovii, opowiada literacko, pięknie, anegdotycznie. Kuczok wyraża się dosadnie, dzięki czemu na pewno nie obrazi się, jeśli usłyszy prostą radę: „Nie Twój cyrk, nie Twoje małpy, Wojciech!”. Dlaczego odmawiam Kuczokowi prawa do publicznego krytykowania władz Legii za okrzyki - zaiste! - małpiej części naszego plemienia? O pierwszej przyczynie już napisałem - nienawidzi Legii, przez co jego wiarygodność w każdym temacie dotyczącym warszawskiego klubu jest zerowa. Jeśli krytykuje Legię - kłamie. Jeśli chwali - też prawdopodobnie kłamie ${ }^{8}$;

Przyczyn może być wiele coś jej napewno jest z tego co opisujesz, może ją gronkowiec zatakował a on otwiera furtkę dla wielu chorób. Odizoluj ją od reszty stada i coś działaj, a jeśli Cię denerwuje i Ci nie zależy to klocka jej sprzedaj i po temacie, Twój cyrk Twoje małpy. Pozdr'.

Frazeologizm nie mój cyrk, nie moje matpy jest w tekstach synonimem wyrażeń to nie moja sprawa, nie obchodzi mnie to bądź kolokwialnych to nie mój interes lub to nie moja broszka. Na podstawie zebranego materiału można stwierdzić, że jest to idiom wielokształtny, a jego wariantywność zasadza się na negacji, czyli zależy wprost od referencji. Stałymi komponentami związku są rzeczowniki cyrk oraz matpy, z czego pierwszy z nich zwykle występuje w wypowiedzeniu na początku. Pojawiają się jednak przykłady, w których realizowany jest odmienny szyk komponentów, tzn. taki, że to człon małpy pojawia się jako pierwszy komponent równokształtny z wyrazem autosemantycznym. Zaimek dzierżawczy występujący przed rzeczownikami cyrk oraz matpy może przybrać formę mój..., moje... lub twój..., twoje.... W większości przykładów negacja obejmuje dwa człony frazeologizmu, aczkolwiek można też znaleźć cytaty, w których jedynie pierwsza część jest zanegowana, natomiast druga nie zawiera partykuły przeczącej, co skutkuje zmianą znaczenia.

7 http://podhale24.pl/aktualnosci/artykul/39078/Co_sie_wydarzylo_na_dworcu_ PKS_w_Nowym_Targu_Awantura_i_szarpanina_miedzy_kierowca_i_pasazere m.html [dostęp: 24.05.2016].

8 http://www.legia.com.pl/pl/33562,Nie_Twoj_cyrk_nie_Twoje_malpy_Wojciech.html [dostęp: 24.05.2016].

9 http://www.pzhgp.pl/forum/viewtopic.php?t=18701 [dostęp: 24.05.2016]. 
Nie mój cyrk, nie moje matpy pojawia się najczęściej w kontekstach politycznych oraz sportowych, zwłaszcza wtedy, gdy potrzebny jest obrazowy zwrot na określenie tego, czy ktoś się czymś przejmuje, czy też przeciwnie - sytuacja go całkowicie nie interesuje i nie dotyczy. Związek ten zawiera dość prostą metaforę, która celnie trafia w sedno przekazu oraz dobrze spełnia swoją funkcję komunikacyjną, stąd pewnie i jego popularność w tekstach ostatnich lat. Na poręczność jego użycia mogło wpłynąć również to, że przekazuje znaczenie synonimicznej frazy nic mnie to nie obchodzi znacznie subtelniej i bardziej plastycznie. Schemat składniowy jest oparty na paralelizmie - najpierw występuje partykuła nie, następnie zaimek mój (/ twój) i kolejno cyrk, a w drugiej części o takim samym początku pojawiają się małpy, dlatego też jest łatwy do zapamiętania.

Lektura angielskojęzycznych blogów oraz stron internetowych przynosi niezwykle interesujące dane materiałowe związane z opisywanym frazeologizmem. Okazuje się, że idiom w postaci not my circus, not my monkeys jest znany użytkownikom angielszczyzny. Skład komponentów tego związku frazeologicznego wskazuje na to, iż możemy mieć do czynienia z kalką z polszczyzny. We wszystkich znalezionych źródłach wielowyrazowiec angielski przyjmuje podaną wcześniej formę, a więc jest dokładnym tłumaczeniem polskiej wersji nie mój cyrk, nie moje małpy. W języku angielskim frazeologizm występuje w jednym ustalonym wariancie (nie odnotowano obecnych w polszczyźnie wariantów z innym układem składników lub innymi komponentami). Poszukiwania zapisów artykułów hasłowych w słownikach angielskojęzycznych (np. Longman Dictionary of Contemporary English ${ }^{10}$ ) bądź też innych wariantów zakończyły się niepowodzeniem. Nasuwa to przypuszczenie, że język angielski zapożyczył frazeologizm z języka polskiego, co jest dość niespotykanym zjawiskiem. Dodatkowo w wielu cytatach autorzy bezpośrednio odnoszą się do polskiego pochodzenia tego zwrotu. Idiomu używa się głównie we wpisach związanych tematycznie z wzajemnym motywowaniem się użytkowników Internetu do pokonywania trudności, coachingiem oraz opowieściami o problemach życia codziennego.

10 Longman Dictionary of Contemporary English, Pearson Education Limited 1978, 2014. Sprawdzono kilka ostatnich wydań, począwszy od $3^{\text {rd }}$ edition (1995), aż do $6^{\text {th }}$ edition (2014). 
Charakterystyczne dla wielu cytatów angielskich jest wprowadzanie przez nadawców do tekstów tzw. operatorów testymonialności:

While more cryptic than just saying "not my problem", the Polish expression "not my circus, not my monkeys" makes perfect sense, and is a lot more fun to say ${ }^{11}$;

A co-worker recently slipped a sign under my door with an old Polish proverb that reads, "Not my circus, not my monkeys"12;

Even as a new staff member, it is ok to say "not my circus, not my monkeys" when you are overwhelmed. This Polish proverb has been one of my favorites since I stumbled across it on Pinterest ${ }^{13}$.

Świadomość polskiego pochodzenia tego frazeologizmu zdradzają również rodzimi użytkownicy innych europejskich języków, co ilustrują zasoby sieciowe. W Internecie pojawia się np. francuskie $c e$ $n$ 'est pas mon cirque, ce ne sont pas mes singes:

J'ai eu beaucoup de plaisir au cours des dernières années à écrire ces lettres occasionnelles d'Asie sur la vie d'un expatrié en Thaïlande et les livres que j'ai écrits pendant que j'étais là, mais la Thaïlande est un endroit très différent de ce qu'elle était lorsque nous nous nous sommes installés à Bangkok il y a plus de vingt ans. Et je suppose que la simple vérité est que j'en ai vraiment marre d'elle. Il y a un vieux dicton polonais qui résume exactement ce que je ressens à propos de la Thaïlande en ce moment: Ce n'est pas mon cirque, ce ne sont pas mes singes ${ }^{14}$.

bądź hiszpańskie no es mi circo, no son mis monos:

La versión en inglés suena mucho mejor que la española (no es mi circo, no son mis monos), pero no es un proverbio anglosajón, sino de origen polaco,

11 http://www.hotelclub.com/blog/idioms-of-the-world-infographic [dostęp: 18.03.2016].

12 K.A. Kennedy, Not my circus, not my monkeys, http://www.huffingtonpost.com/ karen-ann-kennedy/not-my-circus-not-my-monk_b_5390455.html [dostęp: 18.03.2016].

13 R. Johnson, Not my circus, not my monkeys, https://studentaffairscollective.org/ not-my-circus-not-my-monkeys/ [dostęp: 18.03.2016].

${ }^{14} \mathrm{http}$ ://liberez-somyot.over-blog.com/2014/06/ce-n-est-pas-mon-cirque-ce-ne-sont -pas-mes-singes.html [dostęp: 15.07.2016]. 
algo así como "nie mój cyrk, nie moje małpy". No sé nada de polaco, pero eso es lo que encontré al buscar más sobre esta sabia sentencia con la que me topé en Twitter ${ }^{15}$.

Atrakcyjność frazeologizmu not my circus, not my monkeys może być okazjonalna, związana przede wszystkim z chwilową modą językową (np. w przedstawieniach memów internetowych) i trudno powiedzieć, czy idiom ten zostanie w języku angielskim na dłużej. $\mathrm{Na}$ razie $\mathrm{w}$ tekstach angielskich nie pojawiają się warianty tego idiomu, choć jest to możliwe. Zaobserwowanie jego wariantywności będzie potwierdzeniem faktu, że skalkowany polski frazeologizm przyjął się wśród użytkowników języka angielskiego, we frazeologii bowiem uznaje się wielokształtność innowacyjną frazeologizmu za pierwszy etap stabilizacji idiomu ekspansywnego w języku współczesnych użytkowników.

\section{Bibliografia}

Fliciński P., Wielki słownik frazeologiczny, Poznań 2012.

Johnson R., Not my circus, not my monkeys, https://studentaffairscollective.org/ not-my-circus-not-my-monkeys [dostęp: 18.03.2016].

Kennedy K.A., Not my circus, not my monkeys, http://www.huffingtonpost.com/ karen-ann-kennedy/not-my-circus-not-my-monk_b_5390455.html [dostęp: 18.03.2016].

Lebda R., Nowy stownik frazeologiczny, Kraków 2005.

Markiewicz H., Romanowski A., Skrzydlate stowa: wielki stownik cytatów polskich i obcych, Kraków 2005.

Woźniak S., Poznański dzień niepodległości, http://igoronco.natemat.pl/ 38785, poznanski-dzien-niepodleglosci [dostęp: 24.05.2016]

http://blogpress.pl/node/7392 [dostęp: 24.05.2016].

http://liberez-somyot.over-blog.com/2014/06/ce-n-est-pas-mon-cirque-ce-ne-sontpas-mes-singes.html [dostęp: 15.07.2016].

${ }^{15}$ https://saneustaquio.wordpress.com/2014/07/21/not-my-circus-not-my-monkeys/ [dostęp: 24.05.2016]. 
http://podhale24.pl/aktualnosci/artykul/39078/Co_sie_wydarzylo_na_dworcu_PKS _w_Nowym_Targu_Awantura_i_szarpanina_miedzy_kierowca_i_pasazerem.ht $\mathrm{ml}$ [dostęp: 24.05.2016].

http://www.hotelclub.com/blog/idioms-of-the-world-infographic

[dostęp: 18.03.2016].

http://www.legia.com.pl/pl/33562,Nie_Twoj_cyrk_nie_Twoje_malpy_Wojciech.ht $\mathrm{ml}$ [dostęp: 24.05.2016].

http://www.pzhgp.pl/forum/viewtopic.php?t=18701 [dostęp: 24.05.2016].

https://politycznewycinki.wordpress.com/category/na-prawicy/korwin

[dostęp: 24.05.2016].

https://saneustaquio.wordpress.com/2014/07/21/not-my-circus-not-my-monkeys/

[dostęp: 24.05.2016]. 


\title{
The lexicographic comment upon the idiom my circus, my monkeys
}

\begin{abstract}
SUMMARY
This paper is an attempt to present one of not so well-known Polish proverbs, such as my circus, my monkeys. It exactly means that"it is my business, I do care about something because it concerns me". This proverb has some other variants which include adding or altering certain elements of the structure. Usually it consists of two parts - each part has a possessive adjective and a noun. Nouns are always the same - "circus" and "monkeys". There are also cases of changing the order of nouns - either monkeys, or circus comes first. Adjectives can differ; language users choose possessive adjectives on the basis of the context and their preferences. One of more popular variants uses negation in front of each part -Not my circus, not my monkeys. This phrase was borrowed by English in a form of calque. The exact wordfor-word translation exists in online materials in different contexts, usually including the footnote Polish proverb or old Polish proverb. Similar translations were found in other languages, such as Spanish or French. This is an exception in Polish language as it usually borrows elements of lexicon from English or French, not the other way around. The vital part of this paper includes many examples of the usage of this proverb in real-life contexts, taken from online blogs and websites.
\end{abstract}

Key words: not my circus, not my monkeys, Polish proverb, proverbs, borrowing, English-Polish contact, translation, my circus, my monkeys, calque. 


\section{O Autorce:}

Karolina Burnagiel - studentka III roku filologii angielskiej na Wydziale Anglistyki oraz II roku filologii polskiej na Wydziale Filologii Polskiej i Klasycznej Uniwersytetu im. Adama Mickiewicza w Poznaniu. Przygotowuje prace licencjacka na temat zapożyczenia prefiksu re- z języka angielskiego do języka polskiego wraz z jego własnościami syntaktycznymi. Główne zainteresowania badawcze to tendencje rozwojowe współczesnej polszczyzny, składnia i morfologia zarówno jezzyka polskiego, jak i angielskiego, zapożyczenia oraz oddziaływanie jezyków obcych na język polski.

E-mail: karolina.burnagiel94@gmail.com 